\title{
MODYFIKACJE BILANSU ENERGETYCZNEGO W LECZENIU OTYŁOŚCI U DZIECI
}

\section{MODIFICATIONS OF ENERGY BALANCE IN THE TREATMENT OF CHILDHOOD OBESITY}

\author{
Katarzyna Anna Majewska ${ }^{1, a}$, Magdalena Monika Kobylińska, , , Magdalena Tchorzewska-Skrobichº, \\ Monika Korcz-lżykowska ${ }^{1, d}$, Andrzej Kędzia ${ }^{1, e}$ \\ ${ }^{1}$ Katedra Auksologii Klinicznej i Pielęgniarstwa Pediatrycznego, Wydział Nauk o Zdrowiu, Uniwersytet Medyczny im. Karola Marcinkowskiego \\ w Poznaniu \\ ${ }^{2}$ Klinika Diabetologii i Otyłości Wieku Rozwojowego, Uniwersytet Medyczny im. Karola Marcinkowskiego w Poznaniu
}

${ }^{a}$ https://orcid.org/0000-0002-3573-2274
${ }^{b}$ https://orcid.org/0000-0002-3871-2412
${ }^{c}$ https://orcid.org/0000-0001-7821-1404
${ }^{d}$ https://orcid.org/0000-0002-5240-4563
${ }^{\text {e }}$ https://orcid.org/0000-0001-8206-6094

DOI: https://doi.org/10.20883/pielpol.2020.7

\section{STRESZCZENIE}

Częstość występowania otyłości wśród dzieci i młodzieży w Polsce wzrasta, dlatego istotne jest zwiększanie świadomości społeczeństwa na temat zdrowego stylu życia. Podejmowanie kroków mających na celu profilaktykę, a także leczenie otyłości powinno rozpocząć się w jak najmłodszym wieku. Działania powinny dotyczyć zarówno pacjenta, jak i jego rodziny. Postępowanie powinno polegać na instrukcjach dotyczących zasad racjonalnego żywienia oraz na zalecaniu odpowiedniej dla wieku i wydolności aktywności fizycznej. Wśród dzieci, młodzieży i dorosłych zapobieganie, a także leczenie otyłości powinno opierać się na promocji aktywnego trybu życia, zmniejszeniu czasu spędzonego przed telewizorem lub komputerem, propagowaniu spożywania warzyw i owoców, ograniczeniu spożycia przekąsek oraz słodkich napojów i soków. Osoby otyłe w terapii odchudzającej wymagają również pracy nad zmianą zachowań związanych z przyjmowaniem pokarmu. Celem tej pracy było podsumowanie aktualnych zaleceń dotyczących leczenia otyłości u dzieci w różnym wieku w aspekcie możliwych modyfikacji bilansu energetycznego.

SŁOWA KLUCZOWE: otyłość, dzieci, dieta, aktywność fizyczna.

\section{Wstęp}

Zmiany w stylu życia stanowią podstawową metodę leczenia otyłości u dzieci i młodzieży. Modyfikacja bilansu energetycznego jest niezbędna dla uzyskania normalizacji przyrostów masy ciała u młodszych dzieci i spadku masy ciała u młodzieży. Wprowadzenie zmian wymaga wcześniejszej szczegółowej analizy sposobu żywienia dziecka w zakresie zarówno samego składu diety, jak i aspektów behawioralnych związanych z przyjmowaniem pokarmu, by móc wychwycić i skorygować wszystkie istniejące

\begin{abstract}
The prevalence of obesity among children and adolescents in Poland is increasing, which is why it is important to raise public awareness of healthy lifestyle. Taking steps to prevent and treat obesity should start at the youngest age. The actions taken should concern both the patient and his family. They should include education on the principles of rational nutrition and physical activity appropriate for age and condition. Among children, adolescents and adults, prevention and treatment of obesity should be based on the promotion of an active lifestyle, reducing the time spent in front of the TV or computer, promoting consumption of vegetables and fruits, limiting consumption of snacks, as well as sweet drinks and juices. Obese patients during treatment also require efforts to change their eating behaviors. The aim of this paper was to review current guidelines on the treatment of obesity in children of different ages, enabling the necessary modifications of the energy balance.
\end{abstract}

KEYWORDS: obesity, children, diet, physical activity.

nieprawidłowości. Modyfikacje wydatku energetycznego dziecka również wymagają wcześniejszej oceny jego aktywności i wydolności fizycznej oraz sposobu spędzania wolnego czasu, tak by proponowane zmiany były możliwe do realizacji i pozwalały na realne korzyści zdrowotne [1, 2]. Celem tej pracy było podsumowanie aktualnych zaleceń dotyczących leczenia otyłości u dzieci w różnym wieku w aspekcie możliwych modyfikacji bilansu energetycznego.

Wprowadzenie zasad zdrowego stylu życia, obejmującego w pierwszej kolejności zmiany w sposobie 
odżywiania oraz zwiększenie aktywności fizycznej - to najczęstsze zalecenie, jakie otrzymują rodzice dziecka z otyłością w gabinecie lekarskim. To, kim będzie główny odbiorca zalecanych modyfikacji w sposobie żywienia dziecka, zależy od wieku pacjenta. W przypadku małych dzieci - to rodzice lub prawni opiekunowie są odpowiedzialni za zapewnienie im zdrowej diety. Nie można oczekiwać, że dziecko w wieku przedszkolnym, lub wczesno-szkolnym dokona rozsądnego wyboru pomiędzy słodkim napojem a wodą mineralną, stąd w tej grupie pacjentów głównym adresatem zaleceń musi być opiekun. Inaczej kształtuje się sytuacja w przypadku młodzieży. Starsze dzieci dość dużo czasu spędzają poza domem, gdzie mają wiele okazji, by dokonywać samodzielnych wyborów w zakresie odżywiania, a podstawową rolą rodziców jest zapewnienie zdrowej diety w domu. W grupie młodzieży najważniejsze jest uzyskanie właściwej motywacji i zrozumienia problemu, stąd to właśnie sam pacjent musi być głównym adresatem rozmowy dotyczącej modyfikacji sposobu żywienia [1-3].

Podstawowe zalecenia dotyczące sposobu żywienia dzieci i młodzieży obejmują:

- codzienne jedzenie zdrowego śniadania,

- przygotowywanie posiłków w domu zamiast kupowania dań gotowych,

- $\quad$ spożywanie posiłków w gronie rodzinnym przynajmniej 5-6 razy w tygodniu,

- znaczne ograniczenie słodzonych napojów i innych wysokokalorycznych przekąsek - idealne byłoby wyeliminowanie ich w ogóle z diety, jednak dzieci, które spożywają duże ich ilości, skorzystają również ze zredukowania ilości porcji do jednej,

- $\quad$ zwiększenie spożycia warzyw i owoców odpowiednio do wieku dziecka,

- zaangażowanie całej rodziny we wprowadzane zmiany,

- pozwolenie dziecku na samodzielną regulację ilości pokarmu spożywanego w trakcie posiłków i unikanie nadmiernych restrykcji żywieniowych [1-4].

Wymienione wyżej podstawowe zasady żywienia dzieci i młodzieży mogą podlegać indywidualnym modyfikacjom w zależności od wieku i aktywności fizycznej dziecka.

Dieta dzieci powyżej 2. roku życia powinna się opierać szczególnie na warzywach i owocach, produktach pełnoziarnistych, niskotłuszczowych przetworach mlecznych, chudym mięsie i rybach. Zwraca się uwagę na zmniejszenie zawartości w diecie tłuszczów nasyconych i cholesterolu oraz ograniczenie dodawania do posiłków cukru i soli, przy zachowaniu podaży energetycznej odpowiedniej dla wieku i płci oraz stopnia aktywności fizycznej. Spożywane przez dzieci pokarmy powinny również być bogate w błonnik pokarmowy oraz zabezpieczać zapotrzebowanie na makro- i mikroelementy oraz witaminy, ze szczególny uwzględnieniem witaminy D $[5,6]$.

Szczególnym problemem w żywieniu w wieku rozwojowym są tzw. „przekąski”, o małej wartości odżywczej, a dużym ładunku energetycznym [7]. Ilość kalorii, które mogą być dostarczone do organizmu w pokarmie pozbawionym wartości odżywczych, jako czyste źródło energii, wynosi dla dziecka prowadzącego siedzący tryb życia tylko około 100-150 kcal. Jest to mniej niż zawiera przeciętna porcja przekąski czy słodkiego napoju. Jednak wraz ze zwiększającą się aktywnością fizyczną ilość możliwych do przyjęcia w takiej postaci kalorii rośnie do 200-500 kcal, w zależności od wieku, płci i intensywności wysiłku [5].

\section{Szczególne aspekty żywienia małych dzieci (do 2. roku życia)}

Sposób żywienia niemowląt ma istotne znaczenie dla profilaktyki otyłości we wczesnym dzieciństwie. Już od okresu niemowlęcego ważne jest rozdzielenie ról rodzica-opiekuna i dziecka. Rodzic wybiera rodzaj i czas posiłku, dziecko natomiast decyduje o jego objętości. Opiekun musi rozpoznawać i reagować na sygnały sytości u niemowlęcia, by wspomagać u niego kształtowanie samoregulacji ilości przyjmowanego pokarmu, jednocześnie zapobiegając przekarmianiu. Kształtowaniu samoregulacji w pierwszych miesiącach życia sprzyja karmienie naturalne. W drugim półroczu życia można stosować np. metodę BLW (ang. Baby Led Weaning), w której niemowlęciu siedzącemu już samodzielnie podaje się różne pokarmy w takiej postaci, by mogło je samo chwycić, a tym samym samodzielnie regulować wielkość posiłku, oczywiście przy utrzymanym podstawowym karmieniu piersią lub mlekiem modyfikowanym [8].

Pomiędzy 1. a 2. rokiem życia dziecka dochodzi do dalszej przemiany w sposobie żywienia. Poza wzbogacaniem składu diety, kiedy to z żywienia opartego głównie na mleku dziecko uczy się przyjmowania coraz bardziej zróżnicowanych pokarmów i poznaje nowe smaki, dochodzi też do dalszej nauki zasad samodzielnego jedzenia i zachowania przy stole. Szczególnie ważne jest rozwijanie u małych dzieci umiejętności samodzielnego kontrolowania poboru energii z pożywieniem [5, 9].

Nowe, odpowiednio dobrane (,zdrowe”) pokarmy wprowadza się do diety stopniowo. Wykazano, że akceptacja smaku nowych produktów spożywczych jest niekiedy możliwa dopiero po wielokrotnych, nawet ponad dziesięciu próbach ich podania. Dlatego opiekunowie dziecka powinni być o tym informowani, by zniechęceni niepowodzeniem zamiast „uczyć” swoich 
podopiecznych jedzenia owoców i warzyw, nie zgadzanie się na słodycze $[8,9]$.

W składzie diety dziecka pomiędzy 1. a 2. rokiem życia mleko nadal pozostaje ważnym elementem, będąc istotnym źródłem białka, wapnia oraz witamin A i D. Zalecana ilość to 2-3 porcje mleka lub przetworów mlecznych dziennie. Dieta dzieci, które przyjmują nadmierne ilości mleka kosztem zróżnicowanych posiłków, cechuje się nadmierną zawartością tłuszczu i kalorii, jest natomiast zbyt uboga w żelazo. Z kolei u małych dzieci, których spożycie mleka jest zbyt małe na skutek jego „zamiany” na słodzone napoje i soki owocowe, często obserwuje się opóźnione wzrastanie, nadwagę, próchnicę, przewlekłą biegunkę oraz niedobory żywieniowe (m.in. dotyczące wapnia).

Tłuszcz ma większy niż w przypadku węglowodanów i białek ładunek energetyczny i z tego względu jest szczególnie ważnym elementem diety małych dzieci, które mają ograniczoną pojemność żołądka, a jednocześnie duże zapotrzebowanie kaloryczne dla zabezpieczenia intensywnego wzrastania i rozwoju ośrodkowego układu nerwowego. Ograniczanie zawartości tłuszczu w diecie małych dzieci jest niewskazane, gdyż może skutkować opóźnieniem ich wzrastania i negatywnie wpływać na dojrzewanie ośrodkowego układu nerwowego [9].

Dzieci w pierwszych 2-3 latach życia charakteryzują się znaczną plastycznością i w tym czasie łatwo akceptują zmiany, a rodzicom łatwo jest kontrolować ich otoczenie i zachowanie. Ten okres życia wywiera również długofalowy wpływ w zakresie wykształcania nawyków żywieniowych i aspektów behawioralnych związanych z przyjmowaniem pokarmu. Stąd interwencje mające na celu zapobieganie nadmiernemu przyrostowi masy ciała powinny zaczynać się właśnie wtedy. Takie działanie może okazać się najbardziej skuteczne [10].

\section{Szczególne aspekty żywienia dzieci w wieku przedszkolnym (3. do 6. rok życia)}

W tym okresie szczególnym wyzwaniem jest dostarczenie dziecku odpowiedniej ilości składników odżywczych, koniecznych dla prawidłowego rozwoju, unikając jednocześnie nadmiernej podaży kalorycznej [5]. Rodzice lub opiekunowie muszą być świadomi, że to oni są odpowiedzialni za rodzaj podawanego dziecku pokarmu, a także za miejsce i czas posiłku. Natomiast samo dziecko powinno mieć możliwość zdecydowania, czy chce jeść oraz jak dużo zje. Zasada ta dotyczy dzieci, które nie mają niedowagi. Uważa się, że zarówno zmuszanie dzieci do jedzenia, jak i restrykcyjne ograniczanie dostępu do określonych pokarmów nie powinno być stosowane, gdyż może prowadzić z jednej strony do przekarmiania, z drugiej natomiast do nadmiernego zainteresowania zabronionymi produktami [8, 11, 12].

\section{Szczególne aspekty żywienia dzieci w wieku szkolnym (powyżej 6. roku życia)}

Dzieci w wieku szkolnym regularnie jedzą poza domem, bez kontroli rodzicielskiej. W tym wieku często dysponują niewielkimi sumami pieniędzy, za które mogą samodzielnie kupić wybrane produkty pokarmowe w tym chipsy, batoniki, cukierki, słodkie napoje lub inne rodzaje wysokokalorycznych i łatwo dostępnych przekąsek. Schemat spożywania posiłków w ciągu doby przez starsze dzieci i młodzież coraz bardziej odbiega od przyjętej normy, obejmującej śniadanie, drugie śniadanie, obiad i kolację. Obserwuje się obecnie, że wiele dzieci w ogóle nie je śniadania, a ładunek energetyczny pochodzący z przekąsek może nawet przekraczać 30\% kalorii przyjętych w ciągu doby z pożywieniem [5].

Młodzież jest grupą szczególnie narażoną na niezdrowy model żywienia. W tym okresie życia ulega przyspieszeniu tempo wzrastania, a zwiększone potrzeby energetyczne i odżywcze organizmu powodują stymulację apetytu. Zwiększony apetyt w połączeniu z siedzącym trybem życia sprzyja otyłości. W tym wieku ponadto zaznaczona jest już wyraźnie potrzeba podejmowania samodzielnych decyzji, również tych, dotyczących rodzaju spożywanych pokarmów. Presja rówieśników oraz ekspozycja na kierowane do nastolatków reklamy pokarmów typu „fast food” powodują zwiększone spożycie m.in. słodzonych napojów, frytek, pizzy, hamburgerów, zmniejszone natomiast - warzyw, owoców, przetworów mlecznych, produktów pełnoziarnistych, chudego mięsa i ryb. Te zmiany prowadzą w efekcie do nadmiaru w diecie nasyconych kwasów tłuszczowych i cukru, niedoboru natomiast żelaza, cynku, potasu, witamin A, D, C i kwasu foliowego [5, 13].

\section{Restrykcje w żywieniu dzieci z otyłością}

Stosowanie zasad zdrowego żywienia w oparciu o piramidę żywieniową ma kluczowe znaczenie w zapobieganiu rozwojowi otyłości, a także w ograniczaniu nadmiernego przyrostu masy ciała u dzieci z nadwagą. Jednak w przypadku starszych dzieci i nastolatków z otyłością znacznego stopnia sama profilaktyka nie wystarczy konieczne jest uzyskanie ujemnego bilansu energetycznego poprzez zwiększenie aktywności fizycznej oraz uważną analizę dietetyczną z wprowadzeniem ogólnych restrykcji żywieniowych, a w ich następstwie - zmniejszenie ilości przyjmowanych z pokarmem kalorii. Typowym zaleceniem jest ograniczenie cukrów prostych i tłuszczów pochodzenia zwierzęcego w diecie. Jednocześnie należy uwzględnić, że aktywność fizyczna musi być dostosowana do wydolności fizycznej dziecka i nie możemy jej zwiększać bez ograniczeń, szczególnie przy znacznej otyłości. U pacjentów, u których ogólne zale- 
cenia są niewystarczające, konieczne jest indywidualne ustalenie diety hipokalorycznej. Takie postępowanie wymaga opieki dietetyka doświadczonego w pracy z dziećmi, gdyż dieta z ograniczeniem ładunku kalorycznego w wieku rozwojowym musi zapewniać warunki dla prawidłowego rozwoju [2, 3, 14-16].

\section{Aktywność fizyczna}

Aktywność fizyczna jest ważnym elementem wpływającym na rozwój fizyczny i psychiczny dzieci i młodzieży. U dorosłych wpływa na jakość życia, w szczególności na stan zdrowia. Dlatego istotne jest, aby nawyki prozdrowotne kreować już w okresie dzieciństwa. Niestety, postęp cywilizacji przyczynia się do zastępowania aktywnych form spędzania czasu wolnego biernymi, takimi jak: oglądanie telewizji, granie na komputerze czy surfowanie w Internecie za pomocą szerokiej gamy urządzeń [17]. Obniżenie poziomu aktywności fizycznej przyczynia się do powstawania nadmiernej masy ciała, gdyż zbyt duża podaż energii dostarczonej w diecie nie jest równoważona przez aktywność fizyczną [18]. Dodatkowo wyniki badań wśród populacji dzieci europejskich wykazały, iż dzieci o umiarkowanej aktywności charakteryzowały się istotnie większym otłuszczeniem ciała w stosunku do rówieśników o wysokiej aktywności ruchowej [19].

Otyłość wieku rozwojowego ma wpływ na wiele sfer życia. Niektóre konsekwencje zdrowotne mogą pojawić się w dzieciństwie, większość jednak ujawnia się dopiero w życiu dorosłym: wykazano, że wiążą się z występowaniem między innymi problemów psychicznych i społecznych. Dzieci z otyłością mają mniejsze poczucie własnej wartości, miewają stany depresyjne, wykazują trudności w nawiązywaniu kontaktów, a także patologiczne metody rozładowywania emocji w postaci napadowego jedzenia [20].

Otyłość oddziałuje także na sferę somatyczną. Jest czynnikiem wpływającym na występowanie chorób układu naczyniowego, na występowanie cukrzycy typu 2. Zauważa się także zaburzenia gospodarki lipidowej. Nierzadko można stwierdzić odchylenia w układzie kostnostawowym, takie jak koślawość kolan, płaskostopie czy hiperlordoza lędźwiowa. Predysponuje do występowania młodzieńczego złuszczania głowy kości udowej. Otyłość prowadzi do występowania zmian w obrębie układu mięśniowo-szkieletowego. Pacjenci cierpią na zespoły bólowe kręgosłupa, ostrogi piętowe, zespół cieśni nadgarstka. Rzadsze choroby somatyczne to bezdechy senne, choroby wątroby, nerek, nowotwory [20].

Nadmierna masa ciała w wieku rozwojowym wiąże się z obniżoną sprawnością fizyczną, w szczególności dotyczy to wydolności, wytrzymałości, koordynacji i szybkości ruchów. Dzieci prezentują niższy poziom zdolności motorycznych. Barańska i Gajewska przeprowadziły badania sprawności fizycznej za pomocą Europejskiego Testu Sprawności Fizycznej - EUROFIT wśród 55 dzieci z nadwagą lub otyłością. Składa się on z 9 prób, które mają na celu badanie takich zdolności jak: siła, szybkość, wytrzymałość, koordynacja i zwinność. Okazało się, że otyłe dzieci prezentują mierne wyniki próby gibkości, szybkości i siły funkcjonalnej w porównaniu ze zdrowymi rówieśnikami, jedynie siła ręki podczas pomiaru dynamometrem wzrastała wraz ze wzrostem masy ciała [20, 21].

Inne badanie przeprowadzono wśród 92 dzieci w wieku 11-12 lat, którym obliczono BMI, przeprowadzono ankietę dotyczącą aktywności ruchowej oraz wykonano ocenę sprawności fizycznej za pomocą testu Zuchory. Stwierdzono istotne statystycznie zmniejszenie poziomu sprawności fizycznej dzieci wraz ze zwiększeniem BMI [22].

\section{Rehabilitacja w otyłości}

Rehabilitacja dziecka z otyłością jest długotrwałym, kompleksowym procesem, którego celem jest edukacja prozdrowotna oraz pomoc w osiągnięciu odpowiedniego poziomu funkcjonowania i niezależności. Działania powinny mieć charakter interdyscyplinarny, polegający na współpracy między wieloma specjalistami, dzieckiem oraz jego środowiskiem [23, 24]. Postępowanie powinno obejmować następujące elementy: edukację chorego i jego rodziny, odpowiednią dietę, program ćwiczeń fizycznych oraz psychoterapię. Priorytetem w leczeniu otyłości wieku rozwojowego jest utrzymanie stabilnej masy ciała, przy niedużej otyłości aż do czasu zakończenia wzrastania bądź kontrolowanie spadku masy ciała i utrzymanie efektów jak najdłużej [20].

Edukacja pacjenta powinna obejmować przyczyny i skutki otyłości, zasady prawidłowego odżywiania oraz znaczenie aktywności fizycznej. Poprzez podejście behawioralne należy wprowadzać zasady zdrowego stylu życia [20, 25]. U dzieci z otyłością jedzenie jest środkiem poprawiającym humor, jest celebrowaniem okazji, sposobem na spędzanie wolnego czasu, a także dodatkiem podczas czytania czy oglądania telewizji. Podczas zmiany nawyków żywieniowych istotne jest oddzielenie tych czynności od siebie. Należy znaleźć inne sposoby rozładowywania smutku [26]. Bardzo ważne jest motywowanie dzieci osiągających poszczególne cele składające się na zmianę nawyków i redukcję masy ciała [20].

Zalecenia dietetyczne polegają na uzyskaniu ujemnego bilansu energetycznego poprzez ograniczenie podaży kalorii. Zaleca się przyjmowanie pięciu posiłków w ciągu dnia oraz przyjmowanie 1,5-2 litrów płynów na dzień.

Najistotniejszy element leczenia otyłości stanowi systematyczna aktywność fizyczna, która dobrana jest 
indywidualnie do dziecka. Jednak badania pokazują, że najlepsze efekty redukcji masy ciała można uzyskać stosując dietę w połączeniu z programem ćwiczeń. Oprócz systematycznego udziału w zajęciach sportowych pacjenci powinni zamienić czas spędzany w bezruchu na dodatkową aktywność fizyczną [27].

Oprócz spadku masy ciała istnieje jeszcze wiele innych korzyści uprawiania aktywności fizycznej: zwiększenie gęstości kości, wydolności, regulacja gospodarki łłuszczowej, wzmacnianie mięśni i aparatu więzadłowego, zwiększenie gibkości, poprawa koordynacji i umiejętności ruchowych, co wpływa na zmniejszenie ryzyka urazów sportowych [20].

Najlepszą formą aktywności w otyłości jest wysiłek tlenowy, taki jak: jazda na rowerze, bieganie, marsz czy pływanie [28]. Dodatkowo u dzieci powyżej 11. roku życia trafne jest wprowadzanie ćwiczeń oporowych dużych grup mięśniowych [20]. Do programu ćwiczeń powinny być wprowadzane ćwiczenia równoważne, koordynacyjne, kształtujące prawidłową postawę ciała oraz ogólnousprawniające, kształtujące różne umiejętności ruchowe [29].

Ponieważ ćwiczenia powinny być wykonywane regularnie, muszą być dobrane do wieku, możliwości i zainteresowań dziecka [27]. Najkorzystniejsze są zajęcia grupowe, w formie zabawowej, gdyż wpływają na zwiększenie motywacji u pacjentów. Według WHO, zalecana aktywność fizyczna dla dzieci w wieku 5-17 lat powinna wynosić minimum 1 godzinę dziennie [30].

Ze względu na to, że rehabilitacja jest procesem długotrwałym i żeby osiągnąć sukces konieczna jest wytrwałość, motywacja i silna wola, nierzadko potrzebne jest wsparcie psychologa. Celem pracy z pacjentem i jego rodziną jest nauka zmiany myśli z negatywnych na pozytywne, nauka samoakceptacji, praca nad radzeniem sobie z trudnościami, nauka asertywności [20].

\section{Rola pielęgniarki w opiece nad dzieckiem z otyłością}

W leczeniu otyłości dziecięcej kluczowe znaczenie ma wczesna identyfikacja problemu i szeroka edukacja. Ten proces może zachodzić w szpitalu dziecięcym, poradni lekarza rodzinnego czy szkołach i przedszkolach, a istotną rolę powinien pełnić w nim odpowiednio przygotowany personel pielęgniarski. W pierwszej kolejności należy aktywnie identyfikować dzieci otyłe, co wymaga od pielęgniarek znajomości zasad rozpoznawania otyłości u dzieci. Badania wskazują, że wiele otyłych dzieci i ich rodziców wykazuje zaburzone postrzeganie własnej sylwetki z niedoszacowaniem realnej masy ciała - stąd samo uświadomienie opiekunom istnienia problemu jest niezbędne do wdrożenia jakiegokolwiek postępowania, gdyż trudno oczekiwać wprowadzania zmian w stylu ży- cia przez rodziców, którzy uważają, że ich dziecko ma prawidłową masę ciała [4, 31]. Następnie rodzice i dziecko powinni zostać objęci edukacją w zakresie zdrowego stylu życia z uwzględnieniem piramidy zdrowego żywienia i aktywności fizycznej. Należy jednak zaznaczyć, że właściwe przygotowanie personelu jest niezbędne do skutecznej interwencji. W badaniu przeprowadzonym w Szwajcarii, obejmującym ponad 800 pielęgniarek i lekarzy, znaczna część personelu medycznego zgłaszała gotowość do włączenia się w opiekę nad osobami z otyłością, jednocześnie zgłaszając brak odpowiedniego przygotowania, dla przykładu: jedna trzecia badanych nie potrafiła obliczyć wskaźnika BMI (ang. body mass index) [32]. W obliczu narastającego problemu otyłości w społeczeństwie, obejmującego również dzieci, wzrasta konieczność intensyfikacji profilaktyki i leczenia otyłości. Wymaga to szerokiego zaangażowania personelu medycznego: lekarzy, pielęgniarek, dietetyków, psychologów.

\section{Podsumowanie}

Zalecenia dotyczące zmian w sposobie żywienia dzieci z otyłością muszą być w każdym przypadku indywidualizowane i dopasowane do ich wieku, płci i aktualnego trybu życia, zwłaszcza stopnia aktywności fizycznej. Szczególnej uwagi wymagają małe dzieci - coraz częściej obserwuje się otyłość u dzieci przed ukończeniem 3. roku życia, a nawet w okresie niemowlęcym. Ta grupa pacjentów wymaga dokładnej analizy sposobu żywienia i ostrożnych zmian, zmierzających nie tyle do uzyskania redukcji masy ciała, co do racjonalizacji diety i wprowadzenia zasad zdrowego odżywiania. Im wcześniej udaje się dotrzeć do pacjenta i jego opiekunów, tym przeprowadzona interwencja jest bardziej skuteczna. Niestety, w starszych grupach wiekowych trudniej jest osiągnąć zadowalające efekty w postaci rzeczywistej i długotrwałej modyfikacji sposobu odżywiania, a tym samym zahamowania nadmiernego przyrostu masy ciała lub jej redukcji. Konieczność wprowadzenia zmian w diecie wymaga zrozumienia i akceptacji zarówno samego pacjenta, czyli dziecka z otyłością, jak i jego opiekunów, często również otyłych. Rodzice stanowią dla dzieci swoisty wzorzec zachowań, w tym dotyczących również wyboru określonych pokarmów i sposobu odżywiania, tak więc trudno jest spodziewać się skutecznej modyfikacji diety dziecka, jeśli nie zostanie w ten proces zaangażowana cała rodzina.

Należy pamiętać, że najskuteczniejszą metodą redukcji masy ciała jest połączenie diety z odpowiednią ilością aktywności fizycznej. Dlatego ważne jest wprowadzenie specjalistycznego programu ćwiczeń fizycznych dobranego do pacjenta. Ze względu na to, iż dzieci z nadmierną masą ciała uzyskują słabsze wyniki 
w testach sprawnościowych, konieczne jest podejmowanie działań profilaktycznych i edukacyjnych, które motywowałyby dzieci i ich rodziców do większej dbałości o aktywność fizyczną i zdrowie.

\section{Piśmiennictwo}

1. Barlow SE, Expert Committee. Expert Committee recommendations regarding the prevention, assessment of child and adolescent overweight and obesity: summary report. Pediatrics. 2007; 120: 164-192.

2. Styne DM, Arslanian SA, Connor EL, Farooqi IS, Murad MH, SiIverstein JH, Yanovski JA. Pediatric obesity-assessment, treatment, and prevention: an Endocrine Society Clinical Practice Guideline. J Clin Endocrinol Metab. 2017; 102: 709-757.

3. Mead E, Brown T, Rees K, et al. Diet, physical activity and behavioural interventions for the treatment of overweight or obese children from the age of 6 to 11 years. Cochrane Database Syst Rev. 2017; 6: CD012651.

4. Kupczak-Wiśniowska B, Borgosz J, Podsiadło B, Serzysko B, Jędrkiewicz E. Otyłość u dzieci - problem współczesnego społeczeństwa. Pielęg XXI w. 2017; 16: 44-50.

5. Gidding SS, Dennison BA, Birch LL, Daniels SR, Gilman MW, Lichtenstein AH, Rattay KT, Steinberger J, Stettler N, Van Horn L. Dietary recommendations for children and adolescents: a guide for practitioners: consensus statement from the American Heart Association. Circulation. 2005; 112: 2061-2075.

6. Majorczyk M, Baran M, Jaworek J. Rola witaminy D w rozwoju i przebiegu otyłości. Piel Pol. 2016; 1: 91-97.

7. Bel-Serrat S, Heinen MM, Mehegan J, O'Brien S, Eldin N, Murrin $\mathrm{CM}$, Kelleher CC. Predictors of weight status in schoolaged children: a prospective cohort study. Eur $\mathrm{J}$ Clin Nutr. 2018.

8. Szajewska $H$, Socha P, Horvath A, Rybak A, Dobrzańska A, Borszewska-Kornacka MK, Chybicka A, Czerwionka-Szaflarska M, Gajewska D, Helwich E, Książyk J, Mojska H, Stolarczyk H, Weker H. Zasady żywienia zdrowych niemowląt. Zalecenia Polskiego Towarzystwa Gastroenterologii, Hepatologii i Żywienia Dzieci. Standardy Medyczne/Pediatria. 2014; 11: 321-338.

9. Allen RE, Myers AL. Nutrition in toddlers. Am Fam Physician. 2006; 74: 1527-32.

10. Anzman SL, Rollins BY, Birch LL. Parental influence on children's early eating environments and obesity risk: implications for prevention. Int J Obes. 2010; 34: 1116-24.

11. Birch LL, Fisher JO. Development of eating behaviors among children and adolescents. Pediatrics. 1998; 101: 539-549.

12. Fisher JO, Birch LL. Restricting access to palatable foods affects children's behavioral response, food selection, and intake. Am J Clin Nutr. 1999; 69: 1264-1272.

13. Bowman SA, Gortmaker SL, Ebbeling CB, Pereira MA, Ludwig DS. Effects of fast-food consumption on energy intake and diet quality among children in a national household survey. Pediatrics. 2004; 113: 112-118.

14. Ibarra-Reynoso Ldel R, Pisarchyk L, Pérez-Luque EL, Garay-Sevilla ME, Malacara JM. Dietary restriction in obese children and its relation with eating behavior, fibroblast growth factor 21 and leptin: a prospective clinical intervention study. Nutr Metab (Lond). 2015; 12: 31.

15. Mirza NM, Palmer MG, Sinclair KB, McCarter R, He J, Ebbeling CB, Ludwig DS, Yanovski JA. Effects of a low glycemic load or a low-fat dietary intervention on body weight in obese Hispanic American children and adolescents: a randomized controlled trial. Am J Clin Nutr. 2013; 97: 276-85.

16. Valerio G, Maffeis C, Saggese G, Ambruzzi MA, Balsamo A, Bellone S, Bergamini M, Bernasconi S, Bona G, Calcaterra V, Canali T, Caroli M, Chiarelli F, Corciulo N, Crinò A, Di Bonito P, Di Pietrantonio V, Di Pietro M, Di Sessa A, Diamanti A, Doria M, Fintini D, Franceschi R, Franzese A, Giussani $M$, Grugni $G$, lafusco D, lughetti L, Lamborghini A, Licenziati MR, Limauro R, Maltoni G, Manco M, Reggiani LM, Marcovecchio L, Marsciani A, Del Giudice EM, Morandi A, Morino G, Moro B, Nobili V, Perrone L, Picca M, Pietrobelli A, Privitera F, Purromuto S, Ragusa L, Ricotti R, Santamaria F, Sartori C, Stilli S, Street ME, Tanas R, Trifiró G, Umano GR, Vania A, Verduci E, Zito E. Diagnosis, treatment and prevention of pediatric obesity: consensus position statement of the Italian Society for Pediatric Endocrinology and Diabetology and the Italian Society of Pediatrics. Ital $\mathrm{J} \mathrm{Pe}$ diatr. 2018; 31: 88.

17. Chabros E, Charzewska J, Rogalska-Niedźwiedź M i wsp. Mała aktywność fizyczna młodzieży w wieku pokwitania sprzyja otyłości. Probl Hig Epidemiol. 2008; 89: 58-61.

18. Kiess W, Muller G, Kapellen T, Bottner A. Obesity in childhood and adolescence: epidemiology, etiology, clinical diagnosis and management. Int Semin Pediatr Gastroenterol Nutr. 2001; 10: 3-7.

19. Ekelund $U$ at el. Associations between objectively assessed physical activity and indicators of body fatness in 9- to 10-yold European children: a population-based study from 4 distinct regions in Europe. Am J Clin Nutr. 2004; 80: 584-590.

20. Lenart-Domka E, Kwolek A. Rehabilitacja dzieci otyłych - czy jest rzeczywiście potrzebna? Prz Med Uniw Rzesz. 2007; 1: 99-105.

21. Barańska E, Gajewska E. Ocena sprawności motorycznej występującej dzieci z nadwagą i otyłością. Now Lek. 2009; 78: $182-185$.

22. Kubusiak-Słonina A, Grzegorczyk J, Mazur A. Ocena sprawności i aktywności fizycznej dzieci szkolnych z nadmierną i prawidłową masą ciała. Endokrynol Otył Zab Przem Mat. 2012; 8: 16-23.

23. Foster C, Moore JB, Singletary CR, Skelton JA. Physical activity and family-based obesity treatment: a review of expert recommendations on physical activity in youth. Clin Obes. 2018; 8: 68-79.

24. Majewska K, Skowrońska B, Krasińska A, Kobylińska M, Kędzia A. Znaczenie środowiska wewnątrzmacicznego i rodzinnego dla występowania otyłości u dzieci. Pol Prz Nauk Zdr. 2018; 4: 416-421.

25. Zwiauer KFM. Prevention and treatment of overweight and obesity in children and adolescents. Eur J Pediatr. 2000; 159: 56-68.

26. Pietrzykowska E, Wierusz-Wysocka B. Psychologiczne aspekty nadwagi, otyłości i odchudzania się. Pol Merk Lek. 2008; 143: 472-476.

27. Zegan M, Michota-Katulska E, Lewnadowska M, Boniecka I. Rola podejmowania aktywności fizycznej w profilaktyce oraz wspomaganiu leczenia otyłości oraz cukrzycy typu 2. Med Rodz. 2017; 20: 273-278.

28. Siwiński W, Rasińska R. Aktywność fizyczna jako zasadniczy cel stylu życia i zdrowia człowieka. Piel Pol. 2015; 2: 181-188.

29. Jegier A. Regularna aktywność fizyczna jako ważny element promocji zdrowia i prewencji chorób przewlekłych. [W:] Jegier A, Krawczyk J (red.): Wybrane zagadnienia medycyny sportowej. Wydawnictwo PZWL, Warszawa 2012: 52-72. 
30. Global Recommendations on Physical Activity for health, WHO 2011.

31. Szanecka E, Małecka-Tendera E. Postrzeganie masy ciała przez chłopców i ich matki w odniesieniu do ich stanu odżywienia. Endokrynol. Ped. 2013; 12: 45-56.

32. Bucher Della Torre S, Courvoisier DS, Saldarriaga A, Martin XE, Farpour-Lambert NJ. Knowledge, attitudes, representations and declared practices of nurses and physicians about obesity in a university hospital: training is essential. Clin Obes. 2018; 8: 122-130.

Artykuł przyjęty do redakcji: 09.04.2019.

Artykuł przyjęty do publikacji: 30.07.2019.
Źródło finansowania: Praca nie jest finansowana z żadnego źródła. Konflikt interesów: Autorzy deklarują brak konfliktu interesów.

\section{Adres do korespondencji:}

Magdalena Kobylińska

ul. Szpitalna $27 / 33$

60-572 Poznań

tel./fax +48 618491265

e-mail: kobylinska.magda@wp.pl

Katedra Auksologii Klinicznej i Pielęgniarstwa Pediatrycznego,

Uniwersytet Medyczny im. Karola Marcinkowskiego w Poznaniu 